\title{
KOMUNIKASI INTERNASIONAL INDONESIA DALAM MENGHADAPI ANCAMAN SENGKETA LAUT CINA SELATAN DI NATUNA UTARA
}

\author{
Hanifahturahmi \\ STISIP Persada Bunda \\ hanifahturahmi20@gmail.com
}

\begin{abstract}
This study aims to analyze Indonesia's international communication in dealing with the threat of the South China Sea dispute in North Natuna during the reign of Joko Widodo and the factors that influence it. The method used in this study is a qualitative research method with a descriptive analysis approach was applied.The results showed that Indonesia's International Communication in dealing with the threat of the South China Sea dispute during the Joko Widodo Era of Government was to use an idealistic humanistic approach with various diplomatic channels. The message of Joko Widodo's international communication is that Indonesia, along with countries with an interest in the South China Sea, must eliminate sources of conflict at sea, such as fish theft, sovereignty violations, territorial disputes, piracy, and sea pollution. The factors influencing the Joko Widodo's international communication in the South China Sea are grouped into two, namely domestic factors that are focused on Indonesia's national interests, especially in economic development and political stability in Indonesia; and international factors that are focused on conflicts of interest between developed countries which have ambitions to become hegemon in the Asia Pacific Region both economically, politically and defense.
\end{abstract}

Keyword: International communication, diplomatic perspective, South of China Sea

\begin{abstract}
Abstrak
Penelitian ini bertujuan untuk menganalisis komunikasi internasional Indonesia dalam menghadapi ancaman sengketa Laut Cina Selatan di Natuna Utara pada Era Pemerintahan Joko Widodo dan faktor-faktor yang mempengaruhi komunikasi internasional tersebut.Penelitian ini menggunakan metode penelitian kualitatif dengan pendekatan analisis deskriptif. Hasil penelitian menunjukkan bahwa Strategi komunikasi Internasional Indonesia dalam menghadapi ancaman sengketa Laut Cina Selatan pada Era Pemerintahan Joko Widodo adalah menggunakan pendekatan idealistic humanistic dengan berbagai jalur diplomasi. Pesan komunikasi internasional pemerintahan Joko Widodo adalah Indonesia bersama negara-negara yang berkepentingan di Laut Cina Selatan harus menghilangkan sumber konflik di laut, seperti pencurian ikan, pelanggaran kedaulatan, sengketa wilayah, perompakan, dan pencemaran laut. Faktor-faktor yang mempengaruhi komunikasi internasional pemerintahan Joko Widodo di Laut Cina Selatan dikelompokkan menjadi dua, yaitu faktor domestik yang difokuskan pada kepentingan nasional Indonesia terutama dalam pembangunan ekonomi dan stabilitas politik Indonesia; dan faktor internasional yang difokuskan pada konflik kepentingan antara negara-negara maju yang berambisi untuk menjadi hegemon di kawasan Asia Pasifik baik secara ekonomi maupun politik dan pertahanan.
\end{abstract}

Kata kunci: komunikasi internasional, perspektif diplomatik, Laut Cina Selatan 


\section{PENDAHULUAN}

Sengketa Laut Cina Selatan (LCS) melibatkan beberapa negara seperti Republik Rakyat Tiongkok (RRT), Taiwan, Vietnam, Filipina, dan Brunei Darussalam tentang wilayah kedaulatan dan hak maritim. Sengketa LCS memiliki konsekuensi yang besar diluar dari negara-negara yang berkonflik. Dalam sengketa LCS terdapat kepentingan-kepentingan negara besar seperti Amerika Serikat (AS) dan RRT. Walaupun AS pada dasarnya tidak memiliki klaim atas wilayah di LCS, namun Amerika Serikat menegaskan bahwa sengketa ini harus diselesaikan sesuai dengan hukum internasional dan tanpa paksaan atau penggunaan kekuatan. AS bahkan terlibat dalam sengketa antara Filipina dan RRTkarena karena adanya perjanjian AS.-Philippines Mutual Defense Treaty (1951) (Kuok 2014).

Sengketa LCS digambarkan sebagai masalah hubungan internasional yang paling kompleks dan sulit untuk diselesaikan. Bagi negara-negara Asia Timur seperti Jepang, perairan Laut Cina Selatan ini sangat strategis karena lebih dari $80 \%$ impor minyak diangkut melalui perairan tersebut. Selanjutnya, perairan tersebut juga merupakan rute perdagangan Jepang dan Korea Selatan dengan Afrika, Timur Tengah, Eropa, dan sisanya dari Asia. Di sisi lain, Amerika Serikat memiliki kepentingan besar dalam melestarikan perdamaian dan stabilitas di kawasan tersebut karena memberikan pergerakan penting militer Amerika Serikat di seluruh dunia untuk melakukan keamanan strategi global atau untuk tujuan lain membela sekutu-sekutunya (Amry 2015).

Indonesia juga memiliki kepentingan di LCS. Sengketa yang terjadi juga mengancam banyak kepentingan vital Indonesia. Pertama, dari sisi kedaulatan, sebenarnya sebagian wilayah ZEE Indonesia masuk dalam klaim RRT di LCS yang berbatasan dengan perairan Kabupaten Natuna. Kedua, dari sisi keamanan, jika sengketa tersebut tereskalasi menjadi perang, sangat besar kemungkinan perang tersebut akan meluas hingga ke wilayah Indonesia, sehingga menjadi ancaman militer yang serius. Ketiga, dari sisi kepentingan ekonomi, perairan Indonesia di dekat LCS merupakan wilayah dengan potensi perikanan terbesar secara nasional. Pecahnya perang di kawasan ini dapat merusak ekosistem laut sehingga menurunkan jumlah produksi ikan (Raharjo 2014).

Sejak tahun 2009 RRT secara sepihak mengeluarkan peta tradisional yang memuat klaim sembilan garis putus-putus (nine-dash line) yang mengelilingi pulaupulau dan perairan LCS dan klaim tersebut tumpang tindih dengan wilayah perairan Natuna Utara milik Indonesia (Fravel 2016). Akibatnya aksi kapal penjaga pantai RRT dengan leluasa mengganggu penegakan hukum di laut yang sedang dilakukan kapal patroli Kementerian Kelautan dan Perikanan Republik Indonesia (Muhibat 2016). Selain itu perairan Natuna Utara juga menjadi sasaran bagi nelayan kapal asing Vietnam yang melakukan penangkapan ikan dan kapal patroli negara tersebut yang berjaga di wilayah yurisdiksi Indonesia sepanjang tahun 2019 (Ambari 2019).

Berbagai permasalahan yang terjadi di Natuna Utara menjadi semacam peringatan bagi pemerintah Indonesia bahwa terdapat potensi konflik di sekitar Perairan Natuna Utara. Oleh karenanya dibutuhkan sikap yang serius dari pemerintah Indonesia dalam mengkomunikasikan berbagai upaya penyelesaian sengketa agar kedaulatan Indonesia di Natuna Utara tidak terganggu. Indonesia sendiri walaupun tidak terlibat secara langsung dalam aksi saling klaim wilayah di LCS, namun tidak dapat dipungkiri komunikasi internasional Indonesia berperan penting bagi keamanan di kawasan Asia Tenggara. 
Sejak masa pemerintahan presiden Joko Widodo, Indonesia mengusung visi dan misi untuk memajukan kemaritiman Indonesia yaitu dengan menjadi poros maritim dunia. Artinya Indonesia secara aktif akan melakukan pembangunan serta pengamanan menyeluruh di wilayah perbatasan yang menjadi pintu masuk bagi nelayan asing ke Indonesia. Indonesia juga tetap mengedepankan komunikasi internasional yang baik di LCS terutama dalam membantu penyelesaian konflik yang juga akan mengancam keamanan wilayah perbatasan Indonesia di Natuna Utara. Penelitian ini akan membahasperan pemerintah Indonesia sebagai komunikator yang menyampaikan pesan damai kepada seluruh negara yang bersengketa serta faktor-faktor yang mempengaruhi komunikasi internasional Indonesia di LCS.

\section{KONSEP KOMUNIKASI INTERNASIONAL}

Komunikasi internasional merupakan kegiatan komunikasi yang dilakukan oleh pemerintah atau negara dengan pemerintah atau negara lain melalui saluran diplomatik. Jalur diplomatik lebih kerap ditempuh melalui komunikasi langsung antara pejabat tinggi negara (menteri luar negeri, duta besar, konsul jenderal atau staf diplomatik lainnya). Melalui saluran-saluran diplomatik, komunikasi internasional lebih banyak digunakan untuk memperluas pengaruh, meningkatkan komitmen dan solidaritas, menanggulangi perbedaan pendapat dan salah paham. Tujuan komunikasi internasional digunakan untuk mengembangkan kerjasama baik dalam hubungan bilateral maupun multilateral, memperkuat posisi tawar serta meningkatkan citra dan reputasi suatu negara (Shoelhi 2009).

Pesan komunikasi internasional tidak terlepas dari upaya komunikator dalam menanggapi isu internasional. Adapun karakteristik isu internasional menurut James E. Dougherty antara lain: memicu perdebatan dan menarik perhatian para elit negara atau pembuat keputusan dari berbagai negara, atau negara yang memang terlibat dalam isu yang diperdebatkan; diliput secara luas oleh media massa internasional dan berkelanjutan; dan isu yang berlanjut itu kemudian menjadi objek kajian, penelitian, dan perdebatan di kalangan para ilmuwan, pakar, profesional, dan praktisi dalamkomunitas internasional (Shoelhi 2009).

Komunikasi internasional dalam praktiknya menggunakan empat pendekatan dominan, yaitu pendekatan idealistic-humanistic, kepengikutan politik baru (political proselytization), informasi sebagai kekuatan ekonomi, dan kekuatan politik. Komunikasi internasional juga dapat dipahami melalui empat perspektif, yaitu jurnalistik, diplomatik, propagandistik, kulturalistik dan bisnis. Pada penelitian ini penulis menggunakan perspektif diplomatik. Komunikasi internasional dalam perspektif diplomatik merupakan kegiatan komunikasi yang dilakukan oleh pemerintah atau negara dengan pemerintah atau negara lain melalui saluran diplomatik (Shoelhi 2009).

Komunikasi internasional dalam perspektif diplomatik lazimnya digolongkan ke dalam first track diplomacy (komunikasi yang ditujukan kepada pemerintah negara) dan second track diplomacy (komunikasi berhubungan langsung dengan penduduk atau masyarakat setempat (Shoelhi 2009). Menurut McClelland diplomasi adalah pekerjaan komunikasi dan demikian juga kegiatan-kegiatan militer dan tugastugas intelijen(McClelland 1996). Secara umum diplomasidapat didefinisikan sebagai "proses" komunikasi antar pelaku-pelaku politik internasional dan instrumen untuk mencapai tujuan politik luar negeri suatu negara (Djumala 2004). 
Tujuan kegiatan diplomasi adalah pencapaian kepentingan nasional. Kepentingan nasional suatu negara secara khas merupakan unsur-unsur yang membentuk kebutuhan negara yang paling vital, seperti pertahanan, keamanan, militer, dan kesejahteraan ekonomi(Plano and Olton 1999). Kepentingan nasional Indonesia dalam hal ini adalah menjaga keamanan di wilayah perbatasan Indonesia dan peran Indonesia sebagai salah satu negara pendiri ASEAN yang aktif dalam mengkomunikasikan pentingnya keamanan kawasan dengan negara-negara yang bersengketa di LCS.

Kegiatan komunikasi di bidang politik telah banyak menimbulkan efek positif berupa berkembangnya kerja sama internasional yang membuat berkurangnya ketegangan internasional. Namun saat ini, sebagai pelaku komunikasi internasional, negara-negara besar yang berambisi memainkan perannya dalam perpolitikan dunia menyampaikan pesan-pesan yang merupakan contoh yang jelas tentang adanya pengumbaran ambisi-ambisi mereka untuk menjadi yang paling berpengaruh (Shoelhi 2009).

\section{KEPENTINGAN NASIONAL INDONESIA DI NATUNA UTARA}

Konsep kepentingan nasional sangat penting untuk menjelaskan dan memahami perilaku negara dalam sistem internasional. Kepentingan nasional dapat dijelaskan sebagai tujuan fundamental dan faktor penentu akhir yang mengarahkan para pembuat keputusan dari suatu negara dalam merumuskan kebijakan luar negerinya. Kepentingan nasional suatu negara secara khas merupakan unsur-unsur yang membentuk kebutuhan negara yang paling vital, seperti pertahanan, keamanan, militer, dan kesejahteraan ekonomi (Plano and Olton 1999).

Kepentingan nasional secara mendasar dapat dikelompokkan menjadi kepentingan nasional yang bersifat vital atau esensial juga kepentingan nasional yang bersifat non-vital atau sekunder. Kepentingan nasional yang bersifat vital biasanya berkaitan dengan kelangsungan hidup negara tersebut serta nilai-nilai inti (core values) yang menjadi identitas kebijakan luar negerinya. Sedangkan kepentingan nasional non-vital atau sekunder tidak berhubungan secara langsung dengan eksistensi negara itu namun tetap diperjuangkan melalui kebijakan luar negeri (Jemadu 2008).

Kepentingan nasional Indonesia yang terancam dengan adanya sengketa LCS yaitu masuknya wilayah Zona Ekonomi Ekslusif (ZEE) Indonesia ke dalam peta tradisional RRT yang menjadi dasar klaim RRT di LCS serta permasalah batas wilayah perairan dengan Vietnam yang tak kunjung selesai hingga nelayan Vietnam yang gencar melakukan penangkapan ikan di kawasan perairan yang masuk dalam Zona Ekonomi Eksklusif (ZEE) Indonesia(Ambari 2019). Dua faktor ini menjadi perhatian utama karena berdampak pada pelanggaran terhadap hak berdaulat Indonesia di Natuna.

Hak Berdaulat menurut Pasal 56 ayat 1 huruf (a) United Nations Convention On The Law Of The Sea 1982 adalah hak yang mempunyai kekuasaan tertinggi atas keperluan eksplorasi dan eksploitasi, konservasi dan pengelolaan sumber kekayaan alam, baik hayati maupun non-hayati, dari perairan di atas dasar laut dan tanah dibawahnya(United Nations 1982). Dari pernyataan ketentuan pasal 56 United Nations Convention on the Law of the Sea (UNCLOS) 1982 tersebut di atas, Indonesia sebagai Negara pantai mempunyai hak di wilayah Zona Ekonomi 
Eksklusif berupa hak berdaulat untuk melakukan eksplorasi dan eksploitasi, pengelolaan dan konservasi sumber daya alam hayati sedangkan pemanfaatan sumber daya alam non-hayati dianut di dalam rezim hukum Landas Kontinen (Calvin Agasta, Peni Susetyorini 2017).

Berkaitan dengan hak berdaulat tersebut hendaknya dapat digunakan secara optimal dalam rangka memanfaatkan sekaligus melindungi sumberdaya laut dan terhindar dari pencurian ikan dari kapal-kapal asing, sebagaimana diketahui bahwa selama ini sumber daya laut Indonesia di ZEE seringkali diambil secara ilegal oleh kapal negara lain, maka dengan mengoptimalkan hak berdaulat tersebut, Indonesia dapat memanfaatkan dan menikmati sumberdaya laut untuk kesejahteraan masyarakat.

\section{METODE PENELITIAN}

Penelitian ini menggunakan metode penelitian kualitatif (qualitative research) dengan pendekatan analisis deskriptif. Adapun pengumpulan data dalam penelitian ini dilakukan dengan studi kepustakaan. Tujuannya ialah untuk mendapatkan landasan teori mengenai masalah yang diteliti (Sarwono 2006). Peneliti menggunakan model analisis interaktif yang dikemukakan oleh Miles dan Huberman. Model analisis ini terdiri dari beberapa kegiatan: (1) pengumpulan data, (2) reduksi data, (3) penyajian (display) data, dan (4) verifikasi atau penarikan kesimpulan (Sugiyono 2012).

\section{PEMBAHASAN}

\section{Implikasi Sengketa Laut Cina Selatan (LCS) Terhadap Indonesia di Natuna}

Perairan Natuna Utara merupakan kawasan Zona Ekonomi Eksklusif yang berjarak 200 mil, sehingga Indonesia sebagai negara pantai mempunyai hak berdaulat untuk melakukan eksplorasi dan eksploitasi, konservasi dan pengelolaan sumber daya alam, termasuk ikan. Selain sumber daya perikanan, perairan Natuna menyimpan sumber daya minyak dan gas yang potensial. Berdasarkan data terakhir status 1 Januari 2012 diketahui Kabupaten Natuna memiliki cadangan minyak dan gas yang belum dimanfaatkan secara signifikan dan diincar oleh investor Indonesia maupun asing.

Potensi sumberdaya ikan laut Natuna berdasarkan studi identifikasi potensi sumberdaya kelautan dan perikanan Provinsi Kepulauan Riau tahun 2011 adalah sebesar 504.212,85 ton per tahun atau sekitar 50 persen dari potensi WPP 711 sebesar 1.059.000 ton per tahun dengan jumlah tangkapan yang diperbolehkan (80 persen dari potensi lestari) mencapai 403.370 ton(KKP 2016).

Letak kepulauan Natuna sebagai pulau terluar Indonesia di Laut Cina Selatan (LCS) dengan sejumlah potensi alam yang dimilikinya menjadikannya rentan terkena dampak sengketa LCS. Tidak menutup kemungkinan bahwa potensi yang dimiliki oleh perairan Natuna akan dimanfaatkan oleh beberapa negara yang berdekatan dengan wilayah perbatasan Indonesia di Perairan Natuna yang berbatasan langsung dengan LCS.

Wilayah klaim Republik Rakyat Tiongkok (RRT) yang tumpang tindih dengan Natuna Utara berdampak pada keamanan wilayah perbatasan Indonesia terutama 
dari tindakan illegal fishing. Nelayan Tiongkok tercatat sudah tiga kali dikejar dan ditangkap karena tidak memiliki surat izin resmi dari pemerintah Indonesia. Kasus terakhir, penangkapan terhadap kapal bendera Tiongkok Han Tan Cou 19038 yang disertai kawalan kapal penjaga pantai (Coast Guard)(Damastuti et al. 2018).

Selama era pemerintahan Jokowi banyak terjadi aktivitas kapal ikan asing (KIA) di perairan Natuna Utara. Selain kapal penangkapan ikan, juga ditemukan kapal patroli keamanan negara asing. Selain Tiongkok, salah satu negara yang dianggap paling banyak melakukan pelanggaran adalah Vietnam. Hal ini patut diwaspadai mengingat Vietnam merupakan sebuah negara pengklaim di kawasan LCS. Tidak menutup kemungkinan aktivitas-aktivitas kapal Vietnam di Perairan Natuna juga akan berdampak pada ketegangan antara Indonesia dan Vietnam.

Berdasarkan data Kementerian Kelautan dan Perikanan (KKP), sejak tahun 2015 hingga bulan September tahun 2019 KKP telah menangkap sebanyak 603 kapal ikan asing (KIA) yang melakukan illegal fisinging di perairan Indonesia. Kapal ikan asing (KIA) yang paling banyak ditangkap berasal dari Vietnam, yaitu sebanyak 234 kapal. Dari angka tersebut, 81\% melanggar batas Zona Ekonomi Eksklusif (ZEE) Indonesia(Jayani 2019).Berdasarkan data Satgas IUU Fishing 115, tercatat sebanyak 191 dari 234 kapal ikan Vietnam yang ditangkap telah masuk sampai ke dalam batas landas kontinen RI di Laut Natuna Utara(Jayani 2019).

\section{Gambar 5.3. Plotting Posisi Kapal Ikan Vietnam yang ditangkap PSDKP KKP selama periode 2015 - 8 September 2019}

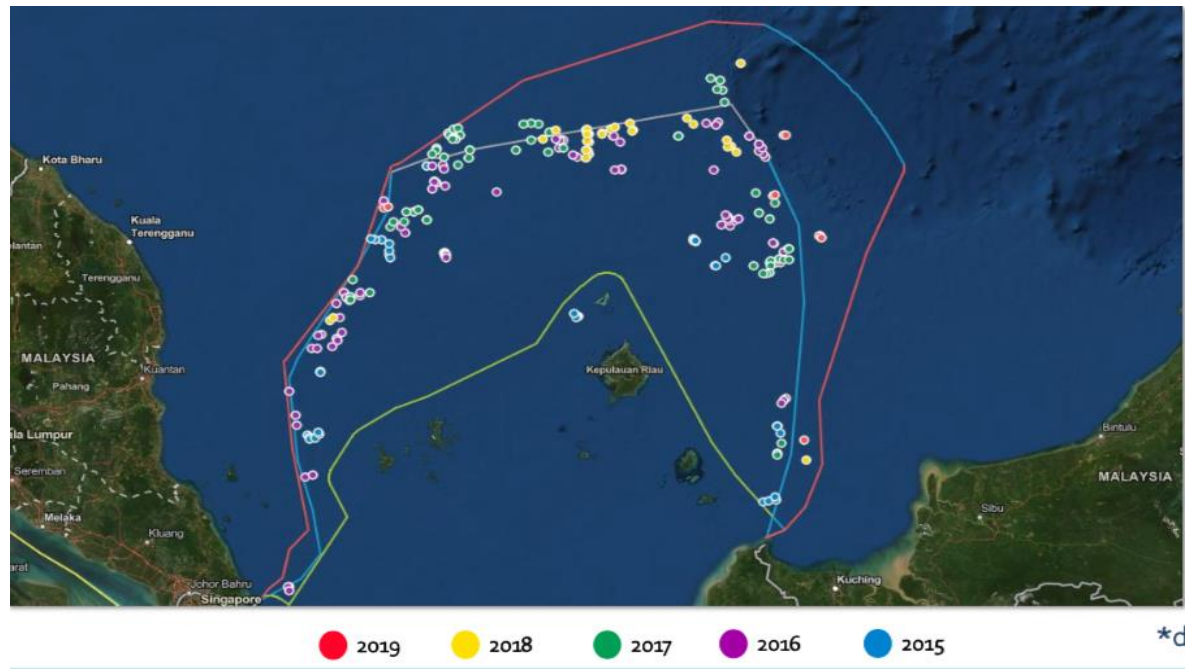

Sumber : Satgas IUU Fishing 115, September 2019

Sepanjang tahun 2019 tercatat sebanyak 91 KIA yang memasuki wilayah perairan Natuna Utara. Selain itu, dalam setahun KKP Indonesia juga menemukan sedikitnya 13 kapal patroli Vietnam yang dengan sengaja bejaga di Laut Natuna Utara yang menjadi Kawasan Landas Kontinen bagi Indonesia(Jayani 2019).Secara tidak langsung, pemerintah Vietnam mendukung aktivitas kapal ikan Vietnam untuk menangkap ikan di sekitar Laut Natuna Utara, sedangkan kapal patroli dari negara manapun dilarang berpatroli di kawasan tersebut. 


\section{Komunikasi Internasional Indonesia dalam Perspektif Diplomatik}

Komunikasi internasional Indonesia dalam menghadapi ancaman dampak sengketa Laut Cina Selatan (LCS) di Wilayah Perairan Natuna Utara pada Era Pemerintahan Joko Widodo salah satunya menggunakan pendekatan idealistic humanistic dengan jalur diplomasi. Sebagai sebuah negara yang berdaulat, Indonesia mampu menjalin hubungan komunikasi yang harmonis demi mencapai dunia yang damai (world peace) sesuai dengan politik luar negeri Indonesia yang bebas aktif.

Di awal masa pemerintahan presiden Joko Widodo, Indonesia telah turut aktif untuk meminimalisir potensi konflik di Laut Cina Selatan (LCS) melalui diplomasi maritim. Diplomasi Maritim Indonesia dalam konteks penyelesaian konflik LCS merupakan negosiasi atau perundingan yang dilakukan oleh dua negara atau lebih mengenai batas laut, kerjasama maritim serta pertahanan (Salim 2016). Hal ini sejalan dengan Visi Indonesia sebagai Poros Maritim Dunia (PMD) yaitu Indonesia sebagai negara maritim yang bardaulat, maju, mandiri, kuat, serta mampu memberikan kontribusi positif bagi keamanan dan perdamaian kawasan dan dunia sesuai dengan kepentingan nasional Indonesia.

Agenda PMD telah dikomunikasikan oleh presiden Joko Widodo kepada para pemimpin negara yang hadir pada KTT Asia Timur (East Asia Summit) tahun 2014 yang diselenggarakan di Nay Pyi Taw, Myanmar. KTT Asia Timur 2014 dihadiri oleh 18 kepala negara, Sekjen PBB Ban Ki Moon, Sekjen ASEAN Le Luong Minh dan Presiden Asian Development Bank Takehiko Nakao.

"Melalui diplomasi maritim, kami mengajak semua mitra-mitra Indonesia untuk bekerja sama di bidang kelautan ini. Bersama-sama kita harus menghilangkan sumber konflik di laut, seperti pencurian ikan, pelanggaran kedaulatan, sengketa wilayah, perompakan, dan pencemaran laut. Laut harus menyatukan, bukan memisahkan, kita semua"(Setiadji 2014).

Presiden Joko Widodo memaparkan 5 pilar utama yang menjadi agenda pembangunan untuk mewujudkan Indonesia sebagai PMD. Kelima pilar tersebut adalah pembangunan kembali budaya maritim Indonesia melalui pendefinisian kembali identitas nasional sebagai bangsa maritim; menjaga dan mengelola sumber daya laut dengan fokus membangun kedaulatan pangan laut; mendorong pengembangan infrastruktur dan konektivitas maritim; melakukan diplomasi maritim untuk membangun bidang kelautan; dan membangun kekuatan pertahanan maritim (Rijal 2013).

Selain melakukan diplomasi maritim, Indonesia juga melakukan peningkatan kapabilitas militernya di Natuna sebagai bentuk diplomasi pertahanan Indonesia dalam menghadapi setiap kemungkinan konflik yang akan melibatkan Indonesia di masa mendatang. Langkah ini dilandasi oleh sikap defensive yang sangat kuat karena Indonesia berupaya menghindari untuk menggunakan kekuatan militernya secara offensive terutama di Kawasan LCS. Sikap offensive di kawasan LCS hanya akan memperumit masalah dan meningkatkan kemungkinan pecahnya perang terbuka skala besar.

Sejak era pemerintahan Susilo Bambang Yudhoyono (SBY) Indonesia berperan sebagai "the honest broker" di LCS. Indonesia memiliki kewajiban untuk terus menjaga netralitasnya terkait sengketa kepemilikan dari fitur-fitur di LCS dan mendorong seluruh claimant states untuk dapat menyelesaikan sengketanya dengan cara-cara damai dan tidak menggunakan kekerasan(Connelly 2017). Peran 
Indonesia ini tidak terlepas dari prinsip kebijakan luar SBY 'Thousand Friends,Zero Enemy'. Prinsip ini dinilai tidak lagi relevan dengan kepentingan Indonesia di LCS saat ini karena memunculkan persepsi bahwa Indonesia memiliki bargaining politik yang lemah di kancah dunia Internasional.

Berbeda dengan langkah yang ditempuh oleh SBY, pemerintahan Joko Widodo mengeluarkan kebijakan yang lebih tegas dalam perannya di LCS. Penafsiran politik luar negeri bebas aktif bukan berarti Indonesia harus netral dan tidak memihak. Indonesia dapat condong atau bahkan memihak kepada blok manapun dengan meninjau kepentingan nasional Indonesia.

Bagi pemerintahan Joko Widodo, pembangunan kekuatan pertahanan di Natuna tidak ditujukan sebagai bentuk perlombaan senjata, melainkan upaya pencapaian standar profesionalisme angkatan bersenjata, dengan mendasarkan pada visi, misi, nawacita, dan kebijakan Poros Maritim Dunia (PMD) (Kemenhan RI 2015).Peningkatan kapabilitas militer juga dianggap penting mengingat Kawasan LCS tidak hanya menjadi ranah konflik antara negara-negara pengklaim, namun juga menjadi ranah konflik kepentingan antara negara-negara major power seperti Amerika Serikat dan Uni Eropa dan sekutu seperti Australia, Korea Selatan serta Jepang. Kepentingan negara-negara ini mulai terlihat ketika Tiongkok mengklaim seluruh wilayah di LCS dan menolak Arbitrase Pengadilan Tetap di Den Haag pada tahaun 2016 tentang penyelesaian sengketa dengan Filipina di wilayah LCS(Salim 2016).

Konflik kepentingan negara-negara major power ini juga di jelaskan dalam lampiran Peraturan Badan Nasional Pengelola Perbatasan Nomor 1 Tahun 2015 tentang Rencana Induk Pengelolaan Perbatasan Negara Tahun 2015-2019 bahwa:

“....terdapat permasalahan dalam konteks penguatan keamanan kawasan yang berpotensi konfilk antar negara, yakni kehadiran penguatan armada laut pemerintah China di klaim area tumpang tindih dengan enam negara di kawasan (Natuna Spratley - Paracell), yang dapat dianggap sebagai persepsi potensi ancaman langsung terhadap keseimbangan lanskap keamanan kawasan. Kerjasama latihan Angkatan Laut Amerika Serikat-India-Jepang dan Australia bersandi Exercise Malabar, berbagai forum kerja sama dan inisiatif di kawasan, pakta militer, kerja sama pembangunan, merupakan respon halus dan pesan nyata terhadap negaranegara yang mencoba merubah ekuilibrium politik dan keamanan kawasan."(BNPPRI 2015)

Indonesia meskipun bukan merupakan claimate state, akan tetapi mempunyai kepentingan karena wilayah Kepulauanan Natuna yang terletak di Kawasan LCS. Kepentingan tersebut setidaknya ada dua, yaitu pertama mencegah spill over konflik ke wilayah kedaulatannya dan kedua adalah memperkuat klaim wilayah ZEE Indonesia di Laut Natuna Utara yang rentan dengan aktivitas illegal fishing.

Gaya komunikasi pemerintah pada era Joko Widodo dengan pemerintahan sebelumnya cukup berbeda. Diplomasi maritim yang digagas oleh Indonesia mengandung prinsip Pembukaan UUD 1945, yang berbunyi ikut melaksanakan ketertiban dunia berdasarkan kemerdekaan, perdamaian abadi dan keadilan sosial. Prinsip yang dianut oleh Republik Indonesia yang berdiri pada tahun 1945 itu memiliki arti penting bagi stabilitas keamanan dunia dan kawasan. Sehingga pada tahun 1960, Indonesia mengeluarkan prinsip politik luar negeri bebas aktif sebagai tindak lanjut dari amanah Pembukaan UUD 45. Namun demikian, penyelesaian 
permasalahan perbatasan maritim dengan menggunakan diplomasi maritim tetap memperhatikan aspek hukum internasional dan hukum nasional dengan mempertimbangkan kepentingan nasional (national interest) sebagai tujuan utamanya. Selain itu seoptimal mungkin juga dipertimbangkan penyelesaian masalah dengan damai, meskipun tidak menutup kemungkinan perang fisik merupakan konsekuensi yang ditempuh apabila kedaulatan dan national interest Indonesia terpinggirkan.

Pesan yang disampaikan dalam diplomasi maritim menjelaskan bawa Indonesia bersama negara-negara yang hadir dalam KTT Asia Timur 2014 harus menghilangkan sumber konflik di laut, seperti pencurian ikan, pelanggaran kedaulatan, sengketa wilayah, perompakan, dan pencemaran laut (Salim 2016). Pesan ini sangat penting bagi kepentingan nasional Indonesia mengingat wilayah perairan Natuna yang sangat potensial dan dapat dimanfaatkan untuk pembangunan nasional Indonesia.

Indonesia menyikapi dengan tegas permasalahan illegal fishing yang terjadi di perairan Natuna.Berbagai pelanggaran yang terjadi di Perairan Natuna pastinya mengancam nelayan-nelayan lokal setempat karena berkurangnya stok ikan yang ada akibat aksi pencurian ikan yang dilakukan oleh nelayan asing. Sementara itu nelayan asing seperti nelayan Tiongkok dilindungi oleh pemerintahnya dengan asumsi bahwa wilayah yang menjadi tempat mereka melakukan penangkapan merupakan wilayah tradditional fishing rights Tiongkok. Klaim Tiongkok didasarkan pada peta sejarah China bukan berdasarkan UNCLOS. Begitu pula halnya dengan nelayan Vietnam yang melakukan aktivitas illegal fishing. Aktivitas nelayan Vietnam juga dilindungi oleh pemerintahnya. Hal ini dibuktikan juga dengan tertangkapnya beberapa kapal patroil Vietnam yang berjaga di wilayah yang seharusnya terlarang bagi kapal patroli selain milik Indonesia.

Dalam merespon tingginya aktivitas illegal fishing di perairan Natuna, Indonesia telah memprakarsai Konvensi Regional tentang IUU Fishing yang diharapkan dapat terbentuk melalui penyelenggaraan Regional Conference on the Establishment of a Regional Convention against Illegal, Unreported, Unregulated (IUU) Fishing and Its Related Crimes secara berkala. Selain itu, Pemerintah Indonesia melalui Kementerian Kelautan dan Perikanan (KKP) telah menyelenggarakan Symposium Fisheries Crime (Fish CRIME) atau Simposium Internasional Kejahatan Perikanan pada Oktober 2016 sebagai wujud diplomasi maritim Indonesia untuk memerangi kejahatan illegal fishing dengan negara-negara lainnya (Riska 2017).

Pencegahan peningkatan aktivitas illegal fishing yang dilakukan oleh KIA Vietnam di Laut Natuna Utara juga sudah diupayakan oleh pemerintah Indonesia sejak 21 Agustus 2019 dalam technical meeting ke-12 perundingan ZEE Indonesia Vietnam di Surabaya. Berdasarkan informasi Direktur Hukum dan Perjanjian Kewilayahan Kementerian Luar Negeri RI, Indonesia dan Vietnam sepakat memulai menyusun pengaturan sementara di klaim tumpang tindih Zona Ekonomi Eksklusif (ZEE) di Natuna Utara sebagai bagian upaya menghindari insiden aparat kedua negara melalui penguatan komunikasi, tindakan menahan diri, dan pembatasan kegiatan perikanan (Kemlu RI 2019).

Hubungan antara Indonesia dan negara-negara yang bersengketa di Laut Cina Selatan (LCS) hinga saat ini masih berjalan baik, walapun beberapa negara memperburuk hubungan Intersebut. Indonesia tetap melakukan berbagai upaya 
diplomasi dalam penyelesaian permasalahan perbatasan dan illegal fishing baik itu melalui first track diplomacy yaitu dengan menunjukkan komunikasi langsung kepada pemerintahan negara yang bersangkutan hingga second track diplomacy dengan melakukan komunikasi kepada masyarakat Natuna dan penduduk asing yang melakukan kegiatan illegal fishing.

\section{Faktor-faktor yang Mempengaruhi Strategi Komunikasi Internasional Pemerintahan Joko Widodo di LCS}

Strategi komunikasi internasional pemerintahan Joko Widodo di Laut Cina Selatan (LCS) dipengaruhi oleh berbagai faktor. Pertama faktor domestik,yang difokuskan pada pembangunan ekonomi dan stabilitas politik. Sejak presiden Joko Widodo menjabat pada tahun 2014, isu maritim menjadi salah satu fokus kebijakan ekonomi dan politiknya. Dalam diplomasi maritim pemerintahan Joko Widodo terdapat agenda pembangunan infrastruktur dalam negeri dengan dana investasi. Badan Perencanaan Pembangunan Nasional memperkirakan bahwa Indonesia memerlukan sekitar $\$ 450$ miliar untuk investasi bidang infrastruktur selama lima tahun dari tahun 2015 hingga 2019, tetapi pemerintah hanya mampu menyediakan sepertiga dari jumlah tersebut. Indonesia mengalami kesulitan dalam tahun-tahun belakangan ini dalam menarik investasi asing langsung pihak swasta untuk proyekproyek infrastruktur penting, yang terhambat oleh reputasi maraknya korupsi serta proses regulasi yang tumpang tindih dan lambat yang mengakibatkan pembebasan tanah dan perolehan izin menjadi sulit (Connelly 2017).

Untuk itu model diplomasi maritim yang digagas oleh pemerintahan Joko Widodo dalam menghadapi dampak sengketa LCS di Natuna Utara, juga difokuskan pada 'diplomasi membumi' yang diartikan sebagai diplomasi yang akan 'berguna bagi rakyat', dengan fokus khusus pada perdagangan dan investasi. Dengan demikian, celah investasi infrastruktur masih dapat diupayakan dan hubungannya dengan negara-negara yang terlibat dalam sengketa LCS tetap baik. Diplomasi membumi juga merupakan suatu langkah rasional yang dipilih oleh pemerintahan Joko Widodo karena kebijakan luar negeri juga semestinya melihat dan mempertimbangkan kondisi masyarakat Indonesia, terutama masyarakat Kepulauan Natuna.

Kedua, faktor internasionalyang difokuskan pada persaingan hegemoni dua negara yaitu Republik Rakyat Tiongkok (RRT) dan Amerika Serikat (AS).Tiongkok dan AS sama-sama berambisi untuk menguasai Asia baik dalam bidang ekonomi, politik maupun pertahanan. Sejak tahun 2011, Presiden Barack Obama telah mengumumkan kebijakan "pivot to Asia-Pacific" Amerika Serikat, yang juga dikenal sebagai kebijakan "rebalance toward Asia". Kebijakan pivot tersebut mencakup keamanan dan ekonomi, dengan mengatur kembali $60 \%$ kekuatan udara dan laut AS ke Asia hingga 2020, mengepung Tiongkok, dan melakukan negosiasi dengan negara-negara sekutu perihal perjanjian Trans-Pacific Partnership, tanpa melibatkan Tiongkok. Efek dari kebijakan containment ini adalah mencegah Tiongkok memperluas pengaruhnya ke wilayah Timur dan Selatan Cina (Kartini 2016).

Kebijakan AS tersebut direspon oleh Tiongkok. Presiden Tiongkok Xi Jinping, pada kunjungannya ke Kazakhstan dan Indonesia pada tahun 2013 mempresentasikan proposalnya terkait kebijakan "Sabuk Ekonomi Jalur Sutra Baru" (the New Silk Road Economic Belt). Presiden Xi Jinping juga mengajukan proposal 
pembentukan hubungan dekat antara Tiongkok dengan komunitas ASEAN dan menawarkan gagasan pembentukan Jalur Sutra Maritim Abad ke-21 $21^{\text {st }}$ Century Maritime Silk Road) untuk mempromosikan kerja sama maritim. Jalur Sutra Maritim ini bertujuan untuk memperkuat hubungan dengan Asia Selatan dan Asia Tenggara, dengan penekanan pada keamanan perdagangan maritim. Kebijakan Jalur Sutra Baru diluncurkan oleh Tiongkok sebagai langkah untuk mengimbangi kekuatan AS di Asia Pasifik (Kartini 2016).

Hal ini tentunya berpengaruh pada komunikasi internasional Indonesia di Laut Cina Selatan (LCS) baik terhadap sikap Tiongkok maupun kepentingan AS. Di satu sisi Indonesia bekerjasama Latihan Angkatan Laut dengan AS sebagai respon dan pesan nyata terhadap negara-negara yang mempengaruhi ekuilibrium politik dan keamanan Kawasan(BNPPRI 2015). Di sisi lain Indonesia juga memanfaatkan kebijakan Jalur Sutra Baru Tiongkok. Kebijakan Jalur Sutra Baru Tiongkok didukung dengan pembentukan Asian Infrastructure Investment Bank (AlIB) untuk mendanai pembangunan infrastruktur dan mempromosikan interkonektivitas regional dan integrasi ekonomi. Gagasan ini juga cocok dengan Master Plan Konektivitas ASEAN dan Visi baru Poros Maritim Dunia yang diajukan Indonesia di bawah pemerintahan Presiden Joko Widodo dengan penekanan pada kekuatan maritime. Persamaan kepentingan antara Tiongkok dengan Indonesia dalam konteks $21^{\text {st }}$ Century Maritime Silk Road dan Poros Maritim Dunia, memberikan peluang bagi kedua negara untuk merealisasikan kebijakan yang menekankan pada pengembangan kekuatan maritim (Kartini 2016).

Dengan demikian, meskipun permasalahan yang terjadi di LCS belum menemukan kejelasan terutama terkait klaim Tiongkok yang tumpang tindih dengan perairan Natuna Utara, hubungan Indonesia-Tiongkok semakin kondusif di bidang ekonomi., terutama kerjasama investasi infrastruktur. Pada dasarnya Indonesia membutuhkan Tiongkok sebagai mitra kerja sama ekonomi dan politik-keamanan, sebaliknya Tiongkok juga demikian. Kondisi saling membutuhkan dan saling mendukung kepentingan nasionalnya ini menjadi pertimbangan dalam komunikasi internasional Indonesia.

Baik Tiongkok maupun AS sebagai negara besar, di lain pihak Indonesia sebagai negara kekuatan menengah berpotensi menuju kepada kerja sama yang diharapkan akan saling menguntungkan bagi kedua negara maupun bagi Indonesia. Oleh karena itu sikap komunikasi yang dibangun oleh Indonesia cukup hati-hati selagi kepentingan antara AS dan Tiongkok dapat dimanfaatkan untuk kepentingan nasional Indonesia.Indonesia tetap mengedepankan prinsip hukum dan etika internasional dalam menentukan strategi komunikasi internasionalnya terkait sengketa yang terjadi di LCS.

\section{KESIMPULAN}

Dalam menghadapi ancaman sengketa Laut Cina Selatan (LCS), Indonesia di bawah pemerintahan presiden Joko Widodo berusaha menjalin komunikasi internasional yang tentunya mengedepankan prinsip hukum dan etika internasional. Artinya, walaupun Indonesia berada dalam satu lingkaran sengketa di LCS, Indonesia tetap berupaya menjaga iklim perdamaian dengan negara-negara yang bersengketa di LCS agar konflik tidak semakin meluas dan mengganggu kepentingan nasional Indonesia. 
Pada praktiknya, komunikasi Internasional Indonesia dalam menghadapi ancaman sengketa Laut Cina Selatan agar tidak menggangu kepentingan nasional Indonesia lebih kepada penggunaan pendekatan idealistic humanistic dengan jalur diplomasi. Dengan pendekatan ini Indonesia berupaya menjalin hubungan komunikasi internasional yang harmonis demi mencapai dunia yang damai (world peace) sesuai dengan prinsip politik luar negeri Indonesia yang bebas aktif.Namun demikian, penyelesaian permasalahan perbatasan maritime Indonesia yang tumpang tindih tetap memperhatikan aspek hukum internasional dan hukum nasional dengan mempertimbangkan kepentingan nasional (national interest) sebagai tujuan utamanya. Dengan demikian pemerintah Indonesia sebaiknya menegaskan kembali pesan komunikasi internasional yang pernah disampaikan oleh presiden Joko Widodo untuk menghilangkan sumber konflik di LCS, yaitu negaranegara yang berkepentingan di LCS harus menghilangkan sumber konflik di laut, seperti pencurian ikan, pelanggaran kedaulatan, sengketa wilayah, perompakan, dan pencemaran laut. Pesan ini sangat penting bagi kepentingan nasional Indonesia mengingat wilayah perairan Natuna Utara yang sangat potensial sering dimanfaatkan oleh nelayan negara asing yang melakukan penangkapan ikan secara ilegal.

\section{REFERENSI}

Ambari, M. 2019. "Ulah Vietnam Ini Mengintimidasi Indonesia Di Laut Natuna Utara." https://www.mongabay.co.id/2019/09/12/ulah-vietnam-ini-mengintimidasiindonesia-di-laut-natuna-utara/ (November 15, 2019).

Amry, Sacha. 2015. "An Analysis of the South China Sea Dispute: Focusing on the Assessment of the Impact of Possible Solutions on the Economies of the Region." City University of New York (CUNY). https://academicworks.cuny.edu/cc_etds_theses/344/.

BNPPRI. 2015. Rencana Induk Pengelolaan Perbatasan Negara Tahun 2015-2019. Indonesia.

http://ditjenpp.kemenkumham.go.id/arsip/bn/2015/BN5902015FIX.pdf.

Calvin Agasta, Peni Susetyorini, L.Tri Setyawanto R. 2017. "Hak Berdaulat Negara Kesatuan Republik Indonesia Di Kepulauan Natuna (Studi Khusus Indonesia Terhadap Klaim Peta Nine-Dashed Line China Di Kepulauan Natuna)." Diponegoro Law Journal 6(2): 1-13.

Connelly, Aaron L. 2017. "Indonesia Di Laut Cina Selatan: Berjalan Sendiri." Maritime Awareness Project.

Damastuti, Tiara Aji, Rivinta Cahyu Hendrianti, Roro Oktavia Laras, and Rahmawati Agustina. 2018. "Penyelesaian Sengketa Ilegal Fishing Di Wilayah Laut Natuna Antara Indonesia Dengan China." Jurnal Reformasi Hukum 1(2): 51-58.

Djumala, Darmansjah. 2004. Hubungan Internasional, Percikan Pemikiran Diplomat Indonesia. Jakarta: Gramedia.

Fravel, M. Taylor. 2016. "Traditional Fishing Grounds and China's Historic Rights Claims in the South China Sea." Maritime Awareness Project.

Jayani, Dwi Hadya. 2019. "Berapa Jumlah Kapal Ikan Yang Ditangkap KKP?" https://databoks.katadata.co.id/datapublish/2019/09/12/berapa-jumlah-kapalikan-yang-ditangkap-kkp (November 17, 2019).

Jemadu, Aleksius. 2008. Politik Global Dalam Teori Dan Praktik. Yogyakarta: Graha 
IImu.

Kartini, Indriana. 2016. "Kebijakan Jalur Sutra Baru Cina Dan Implikasinya Bagi Amerika Serikat." Jurnal Kajian Wilayah 6(2): 131-47.

Kemenhan RI. 2015. Buku Putih Pertahanan Indonesia. Jakarta: Kementerian Pertahanan Republik Indonesia.

Kemlu RI. 2019. "Pertemuan Teknis Ke-12 Batas Maritim RI-Vietnam, Awali Konsultasi Informal Provisional Arrangement." https://kemlu.go.id/portal/id/read/543/berita/ri-vietnam-mulai-perundingan-zeenatuna-utara (January 12, 2020).

KKP. 2016. Potensi Kelautan Dan Perikana Dalam Angka: Kabupaten Natuna. Jakarta: Pusat Data, Statistik, dan Informasi Kementerian Kelautan dan Perikanan.

Kuok, Lynn. 2014. "Overcoming the Impase in the South China Sea: Jointly Defining EEZ Claims." East Asia Policy Paper 4.

McClelland, Charles A. 1996. Ilmu Hubungan Internasional: Teori Dan Sistem. Jakarta: Rajawali Pers.

Muhibat, Shaf F. 2016. "Whither the Honest Broker? Indonesia and the South China Sea." Maritime Awareness Project.

Plano, Jack C., and Roy Olton. 1999. Kamus Hubungan Internasional. Abardin: Bandung.

Raharjo, Sandi Nur Ikfal. 2014. "Peran Indonesia Dalam Penyelesaian Sengketa Laut Tiongkok Selatan." Jurnal Penelitian Politik 11: 55-70.

Rijal, Najamuddin Khairur. 2013. "Smart Diplomacy: Diplomasi Maritim Indoneisia Menuju Poros Maritim Dunia." Global \& Strategis (1).

Riska, Ela. 2017. "Diplomasi Maritim Indonesia Terhadap Aktivitas Penangkapan Ikan Ilegal (Illegal Fishing) Oleh Nelayan China Di ZEEI Perairan Kepulauan Natuna." Prodi Diplomasi Pertahanan 3(2): 33-47.

Salim. 2016. "Peran Diplomasi Maritim Indonesia Dalam Penyelesaian Konflik Laut Cina Selatan (LCS)." Jurnal Maritim Indonesia (Edisi 5).

Sarwono, Jonathan. 2006. Metode Penelitian Kuantitatif \& Kualitatif. Yogyakarta: Graha IImu.

Setiadji, Agus. 2014. "Diplomasi Maritim Untuk Kedaulatan Indonesia." http://maritimnews.com/diplomasi-maritim-untuk-kedaulatanindonesia/.

Shoelhi, Mohammad. 2009. Komunikasi Internasional Perspektif Jurnalistik. Bandung: Simbiosa Rekatama Media.

Sugiyono. 2012. Metode Penelitian Kuantitatif, Kualitatif Dan R\&D. Bandung: Alfabeta.

United Nations. 1982. United Nations Convention On The Law Of The Sea (UNCLOS) 1982. Montego Bay. 